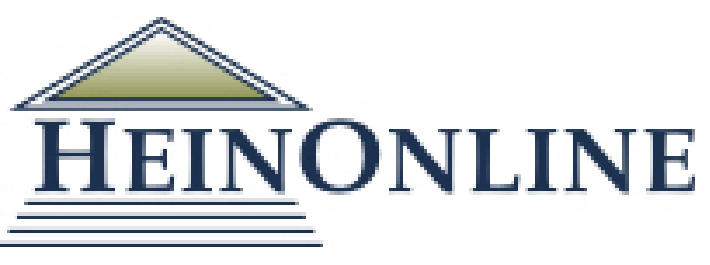

Content downloaded/printed from

HeinOnline

Fri Sep 27 20:25:46 2019

Citations:

Bluebook 20th ed.

Ebenezer Durojaye, When Poverty Is Not a Sin: An Assessment of the Human Rights Council's Guiding Principles on Poverty and Human Rights, 22 Afr. J. Int'I \& Comp. L. 468 (2014).

ALWD 6th ed.

Ebenezer Durojaye, When Poverty Is Not a Sin: An Assessment of the Human Rights Council's Guiding Principles on Poverty and Human Rights, 22 Afr. J. Int'I \& Comp. L. 468 (2014).

APA 6th ed.

Durojaye, E. (2014). When poverty is not sin: An assessment of the human rights council's guiding principles on poverty and human rights. African Journal of International and Comparative Law, 22(3), 468-491.

Chicago 7th ed.

Ebenezer Durojaye, "When Poverty Is Not a Sin: An Assessment of the Human Rights Council's Guiding Principles on Poverty and Human Rights," African Journal of International and Comparative Law 22, no. 3 (2014): 468-491

McGill Guide 9th ed.

Ebenezer Durojaye, "When Poverty Is Not a Sin: An Assessment of the Human Rights Council's Guiding Principles on Poverty and Human Rights" (2014) 22:3 African J of Intl \& Comparative L 468.

MLA 8th ed.

Durojaye, Ebenezer. "When Poverty Is Not a Sin: An Assessment of the Human Rights Council's Guiding Principles on Poverty and Human Rights." African Journal of International and Comparative Law, vol. 22, no. 3, 2014, p. 468-491. HeinOnline.

OSCOLA 4th ed.

Ebenezer Durojaye, 'When Poverty Is Not a Sin: An Assessment of the Human Rights Council's Guiding Principles on Poverty and Human Rights' (2014) 22 Afr J Int'I \& Comp L 468

-- Your use of this HeinOnline PDF indicates your acceptance of HeinOnline's Terms and Conditions of the license agreement available at https://heinonline.org/HOL/License

-- The search text of this PDF is generated from uncorrected OCR text.

-- To obtain permission to use this article beyond the scope of your license, please use: Copyright Information

Use QR Code reader to send PDF to your smartphone or tablet device 


\title{
WHEN POVERTY IS NOT A SIN: AN ASSESSMENT OF THE HUMAN RIGHTS COUNCIL'S GUIDING PRINCIPLES ON POVERTY AND HUMAN RIGHTS
}

\author{
EBENEZER DUROJAYE *
}

\begin{abstract}
There is nothing new about poverty. What is new, however, is that we have the resources to get rid of it ... In the final analysis, the rich must not ignore the poor because both rich and poor are tied in a single garment of destiny. All life is interrelated, and all men are interdependent. The agony of the poor diminishes the rich, and the salvation of the poor enlarges the rich. We are inevitably our brothers' keeper because of the interrelated structure of reality. ${ }^{1}$
\end{abstract}

\section{INTRODUCTION}

Poverty remains one of the greatest challenges facing humanity in this century. Despite the fact that the world is blessed with natural and human resources, a significant number of people, particularly in developing countries, still live in abject poverty. Recent developments show that efforts at combating poverty across the globe are yielding positive results as there seems to be a slight decrease in the number of people living in absolute poverty in poor regions. The picture is not all rosy, however, as there remains great cause for concern because the world's poorest people still live in developing countries. An estimated 1.4 billion people worldwide - the majority of them in South Asia and Africa-survive on less than US\$1 per day. ${ }^{2}$ Equally, approximately 1.2 billion people worldwide are undernourished. ${ }^{3}$ The poverty situation in many developing countries, particularly Africa, is exacerbated by famine, conflict, the lack of access to basic services such

* LLB (Lagos); LLM, LLD (Free State). Community Law Centre, University of the Western Cape, South Africa.

1 M. L. King, Jnr, 'The Quest for Peace and Justice', Nobel Lecture delivered on 11 December 1964, available at http://www.nobelprize.org/nobel_prizes/peace/laureates/1964/kinglecture.html (accessed on 29 March 2014).

2 United Nations, The Millennium Development Goals Report, United Nations (2011), p. 5.

3 Ibid.

African Journal of International and Comparative Law 22.3 (2014): 468-491 Edinburgh University Press

DOI: 10.3366/ajicl.2014.0103

(C) Edinburgh University Press

www.euppublishing.com/ajicl 
as health care, water, sanitation and electricity, unemployment and corruption. While a majority of persons living in extreme poverty are found in developing countries, a pocket of them also live in developed countries.

One of the Millennium Development Goals (MDGs) is to halve the number of people living in poverty across the world by $2015 .^{4}$ While it would seem that the average number of people living in poverty has dropped drastically in some parts of the world, poverty remains widespread in many parts of Sub-Saharan Africa and South Asia. China experienced a drop in poverty rate from 60 per cent in 1990 to about 13 per cent in 2008 , while in South Asia the poverty rate slightly dropped from 54 per cent in 1990 to 36 per cent in $2008 . .^{5}$ On the other hand, the poverty rate in Sub-Saharan Africa fell marginally by 4.8 per cent. ${ }^{6}$ The situation in Sub-Saharan Africa is quite peculiar as the rate of population growth exceeded the rate of poverty reduction. The corollary of this is an increase in the number of people living in extreme poverty from 290 million in 1990 to 356 million in $2008 .^{7}$

Poverty is pervasive across the world not because the world lacks the technology or resources to eradicate it, but because governments, particularly those in developing countries, have not exhibited the political will to combat poverty. It is important to point out that poverty is not an inevitable end to be blamed on the poor, but rather a matter of social injustice. People do not wish to be poor; rather, they are often deprived of the opportunity to lead a worthy life. Experience has shown that many developing countries have failed to adopt positive measures that will improve the living conditions of their people and help them to avoid poverty. Poverty is not a sin; it is a failure of existing institutions to create opportunities for disadvantaged groups to live to their fullest potential. It should be noted that during the World Summit on Social Development in Copenhagen in 1995, the international community committed itself to eradicating poverty in the world. ${ }^{8}$ This was reaffirmed in the Millennium Declaration of 2000, establishing the Millennium Development Goals, which have been termed 'the world's biggest promise'. In September 2012, the United Nations Human Rights Council (HRC) unanimously adopted the Guiding Principles (GPs) on extreme poverty and human rights. The Human Rights Council is the highest UN body responsible for the promotion and protection of human rights across the world. It is an inter-governmental body made of up forty-seven member states of the UN elected by the UN General Assembly. The HRC, which replaces the UN Commission on Human Rights, was created by the UN General Assembly

4MDG 1 of the UN Millennium Declaration and Millennium Development Goals launched in 2000.

5 World Bank, World Development Indicators (WDI) and Global Development Finance (GDF), World Bank (2012) p. 8.

6 Ibid.

7 Ibid.

8 United Nations, Final Report of the World Summit for Social Development (also includes the Copenhagen Declaration and Programme of Action), A/CONF.166/9.

9D. Hulme, 'The Millennium Development Goals (MDGs): A Short History of the World's Biggest Promise', BWPI Working Paper No. 100 (2009). 
on 15 March $2006 .^{10}$ As part of its responsibilities to promote and protect human rights globally, the HRC works with UN special mechanisms such as the Special Rapporteurs and Independent Experts. The HRC is empowered to adopt resolutions and guidelines on relevant human rights issues. Whilst these resolutions and guidelines are not binding, they constitute important direction for states in terms of meeting their human rights commitments at the international level. By adopting the GPs on extreme poverty and human rights, the HRC is making an important statement with regard to a serious issue that troubles the world. Against this background, this paper examines the meaning of poverty and traces the historical development leading to the drafting and adoption of the Guiding Principles. It then analyses the provisions of the Guiding Principles and provide suggestions on how states and civil society groups can use them as effective tools for poverty reduction across the world, particularly in Africa.

\section{UNDERSTANDING POVERTY}

In ordinary parlance, poverty can be described as a situation whereby a person lacks a certain amount of material possessions or money. The word 'poverty' originates from the Latin word 'pauper', that is, poor. ${ }^{11}$ According to the World Bank, poverty can be described as a deprivation in well-being and comprises different dimensions. ${ }^{12}$ These may include low income or the inability to acquire the basic goods and services necessary for survival with dignity. More importantly, poverty encompasses poor access to clean water and sanitation, low levels of health and education, inadequate physical security, and lack of capacity or opportunity to improve one's life.

Poverty has also been defined as a denial of the choices and opportunities necessary for the enjoyment of an adequate standard of living and as a violation of human dignity..$^{13}$ For different people who actually experience poverty at first hand, the term 'poverty' means different things. Hulme et al. have pointed out that the imposition of definitions of poverty from above can become disempowering for the poor. ${ }^{14}$

Some of those who suffer from poverty have described poverty in different ways according to their peculiar experiences. To some people, poverty means not having enough to feed and clothe a family, while to others, poverty means not having a school or clinic to go to, not having the land on which to grow

10 See Resolution 60/225 establishing the Human Rights Council adopted by the UN General Assembly A/RES/60/251.

11 Merriam-Webster Online Dictionary, available at http://www.merriam-webster.com/dictionary/ poverty (accessed 23 May 2014).

12 World Bank, World Development Report, World Bank (2001), p. 6.

13 UN Committee on Economic, Social and Cultural Rights, Poverty and the International Covenant on Economic, Social and Cultural Rights, E/C.12/2001/10, United Nations (2001).

14 D. Hulme, K. Moore and A. Shepherd, Chronic Poverty: Meanings and Analytical Frameworks, Chronic Poverty Research Centre Working Paper No. 2 (2001). 
one's food or a job to earn one's living, or not having access to credit. ${ }^{15}$ Yet others have described poverty to mean insecurity, powerlessness and exclusion of individuals, households and communities, and to some, poverty means susceptibility to violence, and it often implies living in marginal or fragile environments, without access to clean water or sanitation. ${ }^{16}$ There are different dimensions of poverty, and these include income, human, absolute/extreme and relative/moderate poverty. Some of these are defined in more detail below.

\section{A. Income poverty}

This refers to a situation whereby a person is deemed to be poor if, and only if, his or her income is below the defined poverty line. ${ }^{17}$ This approach was popularised by the World Bank, which has relied on income earning to determine the degree of poverty in the world. Usually, any person who earns less than US\$2 per day is said to be poor. Many countries have adopted this approach to measure the progress in reducing the poverty levels in their jurisdictions. The danger with this approach is that it tends to ignore other important socio-economic factors that are crucial to an individual's existence.

\section{B. Extreme poverty}

This is a situation whereby

households cannot meet basic needs for survival. They are chronically hungry, unable to access health care, lack the amenities of safe drinking water and sanitation, cannot afford education for some or all of the children, and perhaps lack rudimentary shelter ... and basic articles of clothing, such as shoes. Unlike moderate and relative poverty, extreme poverty occurs only in developing countries. Moderate poverty generally refers to conditions of life in which basic needs are met, but just barely. Relative poverty is generally construed as a household income level below a given proportion of average national income. The relative poor, in high-income countries, lack access to cultural goods, entertainment, recreation, and to quality health care, education, and other perquisites for upward social mobility. ${ }^{18}$

The World Bank uses this paradigm by measuring a person's income and establishing a 'poverty line' (US $\$ 1$ a day measured in purchasing power parity), which represents an income level below which a person is held to be in extreme

15D. Naraya, R. Patel, K. Schafft, A. Rademacher and S. Koch-Schulte, Voices of the Poor: Can Anyone Hear Us?, World Bank (2000), pp. 5-9. 
poverty. ${ }^{19}$ Another World Bank category, income between US\$1 per day and US\$2 per day, can be used to measure 'moderate poverty' ${ }^{20}$

\section{Human poverty}

This refers to the denial of opportunities to live a tolerable life. The notion of human poverty has been influenced by the work of the renowned Nobel Prizewinning economist, Amartya Sen. According to Sen, poverty often results from deprivation of certain capabilities, which may lead to a state of 'unfreedom' or poverty. ${ }^{21} \mathrm{He}$ argues further that human well-being should not be measured only by income but by the availability of opportunities to lead a decent life. This approach is explored further below. The UNDP has adopted this approach and has tended to define poverty more broadly as the denial of those opportunities and choices most basic to human development - to lead a long, healthy, creative life and to enjoy a decent standard of living, freedom, dignity self-respect and the respect of others. ${ }^{22}$

\section{Poverty as a form of deprivation of opportunities and capabilities}

People are poor not necessarily because they are born poor or choose to be poor, but because they lack certain opportunities, which allow them to avoid poverty. This applies to poor people in both developed and developing countries. Although it must be admitted that the degree or severity of poverty in wealthy countries and poor regions sometimes differs, nonetheless a common denominator of people in poverty in wealthy or poor countries is deprivation of opportunities to avoid poverty. This is known as the 'capability approach' to poverty, which was popularised by Sen. In his seminal book, Development as Freedom, Sen argues that all human beings are endowed with a set of capabilities and unless they are able to realise these capabilities, they are unlikely to escape from poverty or the state of 'unfreedom'. He further argues that despite the fact that the world is richly endowed with human and natural resources, many people live in a state of 'unfreedom' and are unable to realise their capabilities, therefore they lack the needed resources or opportunities to avoid poverty.

In Sen's view, poverty should not merely be measured by low income, but rather should been seen as a deprivation of basic capabilities. ${ }^{23}$ He notes further that constraints on freedom include not just political oppression or interference, but also socio-economic and personal circumstances. According to Sen, 'What people can achieve is influenced by economic opportunities, political liberties, social powers and the enabling conditions of good health, basic education, and

19 T. Allen and A. Thomas (eds), Poverty and Development into the 21 st Century, Oxford University

Press (2000), p. 10.

20 Sachs, supra note 18.

21 A. Sen, Development as Freedom, Oxford University Press (1999), p. 3.

22 UNDP, supra note 17, p. 14.

23 Sen, supra note 21, p. 3. 
the encouragement and cultivation of initiatives'- the capability approach. ${ }^{24}$ Other commentators, such as Alkire and Fukuda-Parr, have echoed the need to look beyond levels of income in measuring poverty in society. ${ }^{25}$ Nussbaum has identified some of the basic capabilities for a life of human dignity to include the capability to live a human life of normal length, to ensure one's bodily health and integrity, to be treated as someone whose worth is equal to that of others, and to have control over one's political and material environment. ${ }^{26}$ In addition, Sen has identified five elemental forms of instrumental freedoms: political freedoms, economic facilities, social opportunities, transparency guarantees and protective security. Each form of freedom is complementary to the others, remaining interrelated and inextricable. According to Sen, these freedoms are crucial to attaining human development.

The World Bank Report on the Voices of the Poor would seem to echo Sen's capabilities approach. ${ }^{27}$ Most of the people interviewed in the report all lamented a state of deprivation and denial of certain opportunities, or what Sen referred to as 'unfreedom'. An important point to note from Sen's capabilities approach is that it focuses on socio-economic and political considerations that are crucial in addressing the causes of poverty in society. In addition, the capabilities approach would seem to coincide with a human rights-based approach to addressing poverty within a state. ${ }^{28}$ It is instructive to note that the UNDP Human Poverty Index of countries in the world is tailored along the capabilities approach. The index is broad and goes beyond measuring level of income but is based on some important indicators which include life expectancy, level of literacy and decent standard of living.

Building on Sen's argument, Nussbaum has observed that attempts to combat poverty in any society must respond to the peculiar circumstances of women. She notes further that since women have historically been disadvantaged, it will be important to put them at the centre of any poverty reduction strategy. ${ }^{29}$ This observation of Nussbaum is quite important, particularly in a region such as Africa, where due to patriarchal traditions and cultural norms women are denied the opportunities to earn a living and live a dignified life.

\section{BACKGROUND TO THE GUIDING PRINCIPLES}

The history of the drafting of the Guiding Principles (GPs) dates back to 1981 when the then United Nations Commission on Human Rights emphasised the need to adopt a rights- based approach to combating poverty across the world.

24 Ibid., p. 5.

25 See S. Fukuda-Parr, 'The Human Development Paradigm: Operationalizing Sen's Ideas on

Capabilities', 9 Feminist Economics (2003): 301-17; see also, S. Alkire, 'Why the Capability

Approach?', 6 Journal of Human Development (2005): 115-33.

26M. Nussbaum, Sex and Social Justice, Oxford University Press (1999), p. 12.

27 Naraya et al., supra note 15, p. 6.

28 A. Sen, 'Human Rights and Capabilities', 6 Journal of Human Development (2005): 152-66.

29 M. Nussbaum, 'Capabilities as Fundamental Entitlements: Sen and Social Justice', 9 Feminist Economics (2003): 33-59. 
Based on this observation, the United Nations former UN Sub-Commission on the Promotion and Protection of Human Rights established a group of experts with a view to preparing a draft of the Guiding Principles on Extreme Poverty and Human Rights. ${ }^{30}$ Prior to this period, the UN General Assembly, through resolution 50/107 of 20 December 1995, proclaimed the first United Nations Decade for the Eradication of Poverty (1997-2006), and took note of the report of the Secretary-General on the implementation of the Decade. ${ }^{31}$ This exemplifies commitments at the international level to combat the menace of poverty. It thus propels actions at both international and national levels towards the eradication of poverty. In 2007, the GPs were resubmitted to the Human Rights Council for further actions.

In 2008, the Human Rights Council mandated the Office of the High Commissioner on Human Rights (OHCHR) to embark on a consultation and organise a seminar with relevant stakeholders with a view to gathering their inputs to the GPs. During this seminar, the content of GPs was shared among participants that included states, civil society groups, United Nations agencies, treaty bodies, special procedure mandate-holders, other intergovernmental organisations, national human rights institutions and nongovernmental organisations (NGOs) for comments and suggestions. The outcome of the seminar and the recommendations made by relevant stakeholders were contained in a report by the Office of the High Commission for Human Rights. ${ }^{32}$ Prior to this period, the UN General Assembly adopted a Resolution to declare the second United Nations Decade for the Eradication of Poverty (2008-17) ${ }^{33}$ This further restates the commitment of the international community to eradicating poverty in the world. Thereafter, the Human Rights Council, through its Resolution 12/17 of 2009, requested the Independent Expert on extreme poverty and human rights (now Special Rapporteur) Ms Magdalena Sepúlveda Carmona, to conduct further study on this and present it with her recommendations on how the document could be improved. Ms Carmona was expected to report back to the Human Rights Council by September of 2010. It is instructive to note that during this period the UN formally converted the position of Independent Expert to that of a Special Rapporteur on extreme poverty and human rights.

Upon the conversion of her mandate from Independent Expert to Special Rapporteur on extreme poverty and human rights in 2008, Ms Carmona conducted series of meetings and made wide consultation with relevant stakeholders,

30 United Nations, The Guiding Principles on Extreme Poverty and Human Rights, available at http://www.ohchr.org/EN/Issues/Poverty/Pages/DGPIntroduction.aspx (accessed 20 February 2014).

31 UN General Assembly Resolution A/58/179.

32 See Report of the High Commission for Human Rights on the Draft Guiding Principles on Extreme Poverty and Human Rights: The Rights of the Poor, United Nations General Assembly, $\mathrm{A} / \mathrm{HRC} / 11 / 32$.

33 Resolution 62/205 of 19 December 2007. 
including representatives of states, UN agencies and civil society groups. ${ }^{34}$ The Special Rapporteur presented her report with recommendations during the 15 th Session of the Human Rights Council in September 2010. The report contained among other things the rationale behind her proposals, the need for conceptual definitions of terms and understanding the main challenges facing people living in extreme poverty for the purpose of the GPs. In addition, the report highlighted the Special Rapporteur's proposal on how the GPs can be improved. ${ }^{35}$ It is important to note that the initial draft of the GPs benefited greatly from an earlier document prepared by Hunt, Nowak and Osmani, which was later revised and published by the Office of the High Commission for Human Rights. ${ }^{36}$ This document emphasises the point that poverty and human rights are intrinsically linked and that any attempts at poverty reduction must reflect human rights principles and standards. In addition, the publication explores other important issues relating to poverty such as participation and empowerment and the relevance of international human rights instruments to poverty reduction. It further examines the importance of accountability, non-discrimination, equality and progressive realisation to poverty reduction. Most of these points are reflected in the GPs.

Following the report of the Special Rapporteur on extreme poverty and human rights, a two-day consultation on the content of the report was organised by the OHCHR on 22 and 23 June 2011 in Geneva. In order for the OHCHR to obtain more precise recommendations and suggestions on the Draft Guiding Principles (DGPs), written submissions were invited from relevant stakeholders and responses were received from experts, states and civil society groups. ${ }^{37}$ After this exercise, the Special Rapporteur then attempted to incorporate into the document the different suggestions and recommendations received. To ensure that all the loose ends were tied, the Special Rapporteur further sought input from experts, representatives of states and civil society groups for the final draft of the GPs. This was presented to the Human Rights Council and unanimously adopted in September 2012. It should be noted that the final adoption of the GPs by the Human Rights Council did not come on a platter of gold. Rather, it was due largely to the efforts of the Special Rapporteur on extreme poverty and human

34 For example, in March 2010, the Special Rapporteur organised a consultation on the Draft Guiding Principles on Extreme Poverty with development practitioners at Brandeis University, and in May 2010 she organised an Expert Consultation on the Draft Guiding Principles in collaboration with the Friedrich-Ebert-Stiftung in Geneva.

35 See Report of the UN Special Rapporteur on Extreme Poverty and Human Rights on the Draft Guiding Principles on Poverty and Human Rights, United Nations Office of the High Commissioner for Human Rights, A/HRC/15/41 available at http:/www.ohchr.org/EN/Issues/ Poverty/Pages/AnnualReports.aspx (accessed 2 June 2014).

36See OHCHR, Human Rights and Poverty Reduction: A Conceptual Framework, United Nations Office of the High Commissioner for Human Rights (2004), available at http://www. ohchr.org/Documents/Publications/PovertyReductionen.pdf (accessed 4 March 2014).

37 See The Draft Guiding Principles on Extreme Poverty and Human Rights: The Rights of the Poor, Office of the United Nations High Commissioner for Human Rights. These responses can be found at htp://www2.ohchr.org/english/issues/poverty/consultation/comments_submissiones.htm (accessed 8 April 2014). 
rights and civil society groups that engaged with representatives of states and other stakeholders to muster support for the adoption of the GPs. The discussion that follows relate to the contents of the GPs and how they can be relevant to the African context.

\section{AN ANALYSIS OF THE PROVISIONS OF THE GUIDING PRINCIPLES}

The GPs are divided into eight sections. It is important to state here that the document is not legally binding on states but only imposes moral obligations on states to implement the content. As the subsequent discussion will show, however, the GPs serve as an important guide for states to adopt appropriate and targeted programmes and policies, rooted in human rights, with a view to achieving poverty reduction. Rather than viewing poverty as a socio-economic problem, the GPs view poverty as the failure of states to create an enabling environment for people to explore their potential and live a dignified life. In this regard, the preamble to the GPs states:

Extreme poverty is not inevitable. It is at least in part, created enabled and perpetuated by acts and omission of States and other economic actors ... Structural and systemic inequalities-social, political, economic and cultural-often remain unaddressed and further entrench poverty. A lack of policy coherence at the national and international levels frequently undermines or contradicts the commitment to combat poverty. ${ }^{38}$

This section of the article examines critically some of the provisions of the GPs, including the general objective of the GPs, the foundational principles, some of the rights relating to extreme poverty the role of duty bearers - state and non-state actors - and the implementation strategies proposed. In particular, it considers the relevance of the GPs to the situation in Africa.

\section{A. Objectives}

This section explains that the GPs are a product of long and sustained consultation with states and other stakeholders. It particularly emphasised that the GPs are meant to provide guidance on how to apply human rights standards to all efforts at combating poverty. To put it more precisely, 'The Guiding Principles are intended as a tool for designing and implementing poverty reduction and eradication policies, and as a guide on how to respect, protect and fulfill the internationally agreed human rights norms and principles ...' 39 These norms and principles include the ones found in international human rights instruments such as the Universal Declaration on Human Rights, the International Covenant on Economic, Social and Cultural Rights, the Convention of the Elimination of All Forms of 
Discrimination against Women (CEDAW) and general comments and concluding observations by treaty monitoring bodies. Although the GPs are silent on the relevance of regional human rights instruments such as the African Charter on Human and Peoples' Rights and the Protocol to the African Charter on the Rights of Women, it can be argued that by the inclusive language of the GPs these instruments are equally relevant in addressing extreme poverty. Indeed, some of the provisions of the African Charter and the African Women's Protocol can be invoked directly or indirectly to address the challenges posed by extreme poverty.

The GPs further aim at 'guiding the application of human rights obligations in policy decisions at both international and national levels, including international assistance and cooperation' ${ }^{40}$ It should be noted that the GPs do not create new implementation obligations on states under international law; rather, states are expected to fulfil their existing obligations under human rights instruments they have ratified. The GPs should be seen as a universal document applicable to states and non-state actors. While the GPs recognise that poverty is ubiquitous and afflicts a significant number of people worldwide, the focus, however, is on those most severely affected by poverty. In other words, the GPs are aimed at protecting persons living in 'extreme poverty' from further marginalisation and human rights abuses. ${ }^{41}$ Given that people living in poverty are often regarded as vulnerable and marginalised, it remains unclear why emphasis is placed on persons living in 'extreme poverty'. A plausible rationale behind this would be to protect the 'weakest of the weak', which is consistent with the mandate of the Special Rapporteur. However, this may give states the wrong impression that poverty reduction policies and programmes must only target those living in 'extreme poverty'. The reality is that in some parts of developing regions, particularly Africa, such a distinction pales in light of the appalling living conditions and the high number of people experiencing poverty in the region. In some countries in Africa, more than 60 per cent of the population is said to be living below the poverty level. ${ }^{42}$ Therefore, in a situation such as this it may become an academic exercise trying to distinguish between those living in poverty and those living in extreme poverty.

\section{B. Foundational principles}

The GPs contain some underlying foundational principles which run through the whole document. These principles are important and serve as benchmarks to assess whether the poverty reduction strategies adopted by a state are faithful to the human rights principles and standards. Some of these foundational principles include dignity, indivisibility and interrelatedness of rights, equality and non-discrimination, respect for the right of the child, agency and autonomy, participation, transparency and access to information and accountability.

40 See ibid.

41 Persons living in extreme poverty are defined as those who live less than US\$1 per day.

42 See for instance, UNDP, Human Development Report 2013: The Rise of the South: Human

Progress in a Diverse World, United Nations Development Programme (2014). 
These principles are no doubt crucial in formulating programmes and policies to combat poverty. One of the consequences of living in extreme poverty is the loss of dignity, self-worth and honour. Extreme poverty diminishes humanity and erodes an individual's self-confidence. Persons living in extreme poverty often encounter shame and rejection and are shunned by others. George Orwell in one of his novels, The Road to Wigan Pier, vividly captures the liability that comes along with being poor in the following words:

In my childhood we were brought up to believe that [the working class] were dirty. Very early in life you acquired the idea that there was something subtly repulsive about a working-class body; you would not get nearer to it than you could help. You watched a great sweaty navvy walking down the road with his pick over his shoulder; you looked at his discoloured shirt and his corduroy trousers stiff with the dirt of a decade; you thought of those nests and layers of greasy rags below, and, under all, the unwashed body, brown all over (that was how I used to imagine it), with its strong, bacon-like reek. ${ }^{43}$

The preamble to the Universal Declaration on Human Rights provides that the recognition of dignity and of the equal and inalienable rights of all individuals is the foundation of freedom, justice and peace in the world. ${ }^{44}$ This clearly warrants that states must take appropriate steps and measures to address extreme poverty among the people. Also, article 4 of the African Charter guarantees the right to dignity of every individual. The African Commission has adopted a purposive interpretation of this provision to include exposing human beings not only to physical suffering but also to psychological suffering. ${ }^{45}$ To allow a significant number of people to wallow in extreme poverty is an indication of failure on the part of a state to meet its human rights obligations. Emphasising this point, the South African Constitutional Court in $S v$ Makwanyane has noted that:

The importance of dignity as the founding value of the new Constitution cannot be overemphasized. Recognizing the right to dignity is an acknowledgment of an intrinsic worth of human beings: human beings are to be treated as worthy of respect and concern. ${ }^{46}$

In essence, African governments must take appropriate measures founded on respect for human dignity in addressing poverty within their jurisdictions. All efforts, including policies and legislation adopted towards addressing extreme poverty in Africa must not only aim at minimising the negative effects of poverty but must also take steps to avoid psychological suffering.

In addition to the right to dignity, the GPs also emphasise the importance of the twin principles of equality and non-discrimination to addressing

43 G. Orwell, The Road to Wigan Pier, Victor Gollancz (1937).

44 Universal Declaration on Human Rights (UDHR) adopted on 10 December 1948, GA Res. 217A(III) UN Doc. A.

45 John K. Modise v Botswana(2000) AHRLR 25 (ACHPR 1997).

46 S v Makwanyane 1995 (3) SA 391(CC). 
extreme poverty. In other words, discrimination may be a cause of poverty and poverty may further perpetuate discrimination and erode an individual's right to equality. This is particularly true for certain groups of people such as women and children who already encounter discriminatory practices on a daily basis. The concepts of equality and discrimination are well recognised in virtually all human rights instruments. Generally, equality presupposes that people in similar situations should be treated alike. This is often referred to as formal equality. Such an approach to equality tends to turn a blind eye to existing disparity in the social and economic lives of people. In other words, it does not take into cognisance the peculiar situation of vulnerable or marginalised members of society who have been historically disadvantaged due either to race, age or gender. ${ }^{47}$ Adherence to formal equality in the real sense does not guarantee true equality but disparity.

On the other hand, a substantive approach to equality tends to recognise the existing disparities in the socio-economic conditions of people. Substantive equality as different from formal equality aims at promoting social justice and egalitarianism in a society, particularly for the marginalised or vulnerable groups. ${ }^{48}$ For instance, a study has shown that women constitute a significant number of people living in poverty and remain the poorest of the poor ${ }^{49}$ Moreover, women are often engaged in informal employment with poor remuneration compared with their male counterparts. It should be noted that the definition of discrimination contained in articles 1 and 2 of the African Women's Protocol is tailored towards realising substantive equality for African women. These provisions tally with the approach adopted by GPs and can be useful in addressing poverty among women. The African Commission has affirmed in the Purohit case that articles 2 and 3 of the African Charter relating to non-discrimination and equality before the law are fundamental provisions of the Charter that are not subject to derogation. ${ }^{50}$ Also, in the SERAC case the Commission found the Nigerian government in violation of various provisions of the African Charter, including article 2, for failing to control the activities of multinational oil companies that interfered with the source of living of the people of Ogoniland. ${ }^{51}$

In many parts of Africa, women continue to play subordinate roles and are often excluded from decision-making processes due to cultural and religious practices. ${ }^{52}$ This in turn limits women's role in economic activities and perpetuates their low status in society. Given this situation and the fact that extreme poverty affects those on the lowest rung of the ladder in society, any intervention by states must not only

47 See E. Durojaye, 'Substantive Equality and Maternal Mortality in Nigeria’, 65 Journal of Legal Pluralism and Unofficial Law (2012): 103, 105.

48 J. Rawls, A Theory of Justice, Oxford University Press (1971).

49 See for instance F. Banda, Laws that Discriminate against Women, Office of the High Commissioner for Human Rights (2008), where the report estimates that 70 per cent of the world's poor are women and that women have less than 1 per cent access to land.

50 Purohit and Moore $v$ The Gambia (2003) AHRLR 96 (ACHPR 2003).

51 Social and Economic Rights Action Centre (SERAC) and Another v Nigeria (2001) AHRLR 60 (ACHPR 2001) (hereinafter SERAC case).

52 Banda, supra note 49 , p. 4. 
be aimed at addressing the existing structural imbalances that lead to poverty but must also take positive or affirmative measures to correct the situation.

Furthermore, the current trends in poverty level across the world reveal deep structural inequalities between developed and developing countries, and haves and have-nots. The playing field between developed and developing countries is not levelled. A world where nearly 18 million people die yearly due to povertyrelated causes and where 15 per cent of the world population enjoys about 80 per cent of the product and 42 per cent of the world's population only enjoys 1 per cent is certainly not an even one. ${ }^{53} \mathrm{~A}$ study has further shown that in 2000 the bottom 50 per cent of adults altogether enjoyed 1.1 per cent of global wealth, while the top 10 per cent had 10 per cent and the top 1 per cent had about $40 \% .^{54}$ This is a clear manifestation of structural disorder and inequality in the distribution of wealth across the world. Pogge has argued that the existing international institutional arrangements are skewed in favour of the high-income countries to the disadvantage of low-income countries, thereby aggravating the poverty situation in the world ${ }^{55} \mathrm{He}$ argues further that the current world economic orders, including the protectionist trade arrangements, are unjust, antithetical to the interests of low-income countries and constitute massive human rights deficits. This observation summarises the social injustice that pervades the world. Sadly, however, the GPs fail to decisively address this concern.

While the GPs include a provision on international support, the language adopted could have been stronger to drive home the point that assisting poor countries is not an act of magnanimity or charity but rather a moral obligation. As Pogge would argue, the poverty situation in most of the low-income countries is as a result of the actions or inactions of high-income countries, therefore it is a matter of justice for rich countries to assist the poor countries of the world. ${ }^{56}$ This would seem to be in line with article 2(1) of the ICESCR which calls for international cooperation and assistance with regard to fulfilling obligations in relation to socio-economic rights. This has also been echoed in MDG 8, where richer countries are enjoined to assist poorer countries in realising their full potential and development. This remains a contested issue as rich countries have argued that they are not under any legal obligation to assist poor countries. ${ }^{57}$ It is sometimes argued that giving aid to poor countries is never a matter of right but rather of charity. Indeed, the history of article 2(1) of the ICESCR shows some disagreement among states as regards the binding nature of the article. ${ }^{58}$

53 World Bank, World Development Report 2006, World Bank (2007).

54 J. B. Davies, S. Sandstrom, A. Shorrocks and E. N. Wolff, The World Distribution of Household Wealth (WIDER 2006), available at http://www.wider.enu.edu (accessed 26 March 2014).

55 T. Pogge, World Poverty and Human Rights, Polity Press (2008), pp. 29-30; see also Davies et al., supra note 54.

56 T. Pogge, 'World Poverty and Human Rights', 19 Ethics and International Affairs (2005): 3.

57 M. Risse, 'Do We Owe the Global Poor Assistance or Rectification?', available at http:/www. hks.harvard.edu/fs/mrisse/Papers/Papers\%20-\%20Philosophy/PoggeIV.pdf (accessed 5 March 2014).

58 See P. Alston and G. Quinn, 'The Nature and Scope of States Parties' Obligations under the International Covenant on Economic, Social and Cultural Rights', 9 Human Rights Quarterly (1987): 156, 188-90. 
At best it may be argued that the obligation to assist is of moral imperative and as such rich countries are morally (but not legally) obligated to assist poor countries. While the African Charter is silent on this issue, the African Commission in its Principles and Guidelines on the Implementation of Economic, Social and Cultural Rights has explained that African governments are obligated to seek external assistance in order to realise socio-economic rights for their people. ${ }^{59}$ In addition, the Commission notes that it is incumbent upon developed countries to render assistance to poor countries. The position of the African Commission on this issue is commendable as it will propel African countries to seek support, internally and externally, in order to address the poverty situation within their jurisdiction.

Oftentimes, persons living in extreme poverty tend to encounter discrimination and stigma in society. Therefore, in affirming a substantive approach to equality, the GPs enjoin states to take appropriate positive measures to protect the de facto equality of all persons living in poverty. The document explains further that such steps must include legislative, executive, administrative, budgetary and regulatory instruments and specific policies and programmes in poverty-sensitive areas such as employment, education, culture, housing, food, health and sanitation. ${ }^{60}$ The African Commission has echoed a similar view by urging African governments to ensure the adoption of remedial measures targeted at improving the conditions of vulnerable and marginalised groups in society. More importantly, the Commission reasons that the provision of basic social services (such as water, electricity, education and health care) and equitable access to resources (such as land and credit) to members of vulnerable and disadvantaged groups' is imperative. ${ }^{61}$

Other important foundational principles underpinning the GPs are participation and empowerment. Participation is an essential element of a democratic society. It entails the recognition of the right of people to be involved in decision making that may affect their lives. As regards persons living in extreme poverty, their ability to participate in policy formulation affecting their lives is crucial to finding a lasting solution to the challenges posed by extreme poverty in society. As the common saying goes, 'he who wears the shoes knows where it pinches'. If a poverty reduction strategy is to succeed, then it is crucial to involve those living in extreme poverty in the design and formulation of policies and programmes for such purpose. Sadly, however, people living in poverty and other marginalised and vulnerable groups are hardly involved in decisions that affect their lives. It should be noted that article 13 of the African Charter guarantees the right to participation.

59 See para. 39 of the Principles and Guidelines on the Implementation of Economic, Social and Cultural Rights in the African Charter on Human and Peoples' Rights adopted by the African Commission during the 48th Ordinary Session held in Banjul, The Gambia, from 10-24 November 2010.

60 Port Elizabeth Municipality v Various Occupiers 20051 SA 217 (CC); Occupiers of 51 Olivia Road, Berea Township, and 197 Main Street, Johannesburg v City of Johannesburg 20083 SA 208 (CC); see also City of Johannesburg Metropolitan Municipality v Blue Moonlight Properties 39 (Pty) Ltd 20122 SA 104 (CC).

61 Principles and Guidelines on the Implementation of Economic, Social and Cultural Rights, supra note 59, para. 2. 
More importantly, the provision of the GPs on right to participation resonates squarely with the African Charter on Participation and Development. The Charter urges African governments to ensure the full participation of the people in the development of policies and programmes on social and economic development. ${ }^{62}$

More recently, the South African Constitutional Court has developed the concept of 'meaningful engagement' in evictions cases. The Court has noted that before the government commences an eviction action, it must show that attempts were made to meaningfully engage with the affected persons. ${ }^{63}$ According to the Court, meaningful engagement is a two-way process where the parties are equal at the negotiating table. Moreover, parties must display utmost good faith and sincerity throughout the process. The benefit of this approach is that it affords the government and the governed to engage with each other and reach a consensus on a particular issue. It is empowering in the sense that it treats vulnerable and marginalised groups as important stakeholders and not as onlookers in decisionmaking that affects their lives. This can be a useful approach that can be developed and adopted by policy makers across Africa in the design and implementation of policies and legislation to address poverty. It will ensure that African governments engage with vulnerable and marginalised groups in developing appropriate laws and policies to combat poverty. Such an approach is powerful and empowering in the sense that it will ensure that the voices and concerns of the most vulnerable and marginalised, that are hardly considered, are reflected in policies, laws and programmes to address poverty.

Other foundational principles contained in the GPs include respect for the right of the child, transparency and ensuring access to information for those living in extreme poverty. The GPs reinstate the fact that most children live in extreme poverty and therefore deserve the special attention of states. More importantly, the GPs rightly note that the girl-child is more susceptible to poverty than her male counterpart. Thus, the GPs enjoin states to adopt appropriate strategies and allocate resources to programmes that protect marginalised children from extreme poverty. In this regard, attention should be given to street children, children with disabilities, victims of trafficking, child heads of households and children living in care institutions. This list should not be seen as exhaustive but rather should be interpreted to include other children that are vulnerable and live at the margins of society.

The need to address poverty among girls is very important in the African context where early or child marriages are rampant. Both the African Children's Charter and the African Women's Protocol prohibit child marriages. Sadly, however, early or child marriages remain widespread in many parts of Africa. Studies have shown that child or early marriages often deny the girl-child the opportunity to attend school and acquire necessary skills useful to gain

62 See The African Charter for Popular Participation in Development and Transformation, adopted in February 1990 at the International Conference on Popular Participation in the Recovery and Development Process in Africa, Arusha, Tanzania, para. 23.

63 See Occupiers of 51 Olivia Road, Berea Township, and 197 Main Street, Johannesburg v City of Johannesburg, supra note 52. 
employment. ${ }^{64}$ Consequently, girls who undergo child marriages are not only deprived the opportunity to attend school but are also likely to tend towards poverty. The Call for Accelerated Action on the Implementation of the Plan of Action towards Africa Fit for Children (Call) adopted by African governments was aimed at improving the overall socio-economic conditions of the African child, particularly the girl-child. The Call enjoins African governments to allocate adequate resources towards strengthening social protection measures for children, particularly vulnerable and marginalised children, including those with special needs and those who are orphaned. Its overall goal is to ensure the commitments of African governments to improving the social well-being of children in the region. ${ }^{65}$ This serves as an important mechanism to address poverty among children in Africa. In addition, the African Commission has emphasised that African governments must take measures to 'protect children and young persons against economic, social and all other forms of exploitation, neglect or cruelty and from being subject to trafficking, ${ }^{66}$

In addition, the GPs emphasise the need to ensure accountability to protect the rights of those living in extreme poverty. To this end, states are to ensure that effective remedies exist for persons living in extreme poverty. This is a very important point that has often been ignored by states. In most parts of the world, particularly Africa, access to justice for the poor remains a mirage. Even when persons living in extreme poverty experience violations of their rights, they find it difficult to seek redress due to the high cost of litigation and other barriers. ${ }^{67}$ Justice should not be seen as belonging to the rich or well-off in society. This can lead to frustration and loss of confidence in the system.

\section{Specific rights}

As noted earlier, one of the fundamental objectives of the GPs is to promote a rights-based approach to addressing poverty. In this regard, the GPs identify different rights that may be violated by reasons of experiencing extreme poverty. In affirming the interrelatedness and indivisibility of rights, the GPs state that persons living in extreme poverty are entitled to both civil and political rights and socio-economic rights. This is consistent with the consensus reached during the Vienna Programme of Action, where it was noted that all human rights -civil and political and socio-economic rights - are universal, indivisible, interrelated and interdependent. ${ }^{68}$ Moreover, it is consistent with the approach of the drafters of the major human rights instruments in Africa, including the African Charter,

64 ICRW, When Marriage Is No Haven ... Child Marriage in Developing Countries: What Works to Keep Girls Safe, International Center for Research On Women (2004), p. 1.

$65 \mathrm{AU}$, Call for Accelerated Action on the Implementation of the Plan of Action towards Africa Fit for Children (Call): mid-term review, 29 October-2 November 2007, African Union.

66 Principles and Guidelines on the Implementation of Economic, Social and Cultural Rights, supra note 59.

67 See the Report of the Special Rapporteur on Extreme Poverty and Human Rights on Access to Justice, August 2012, A/67/278.

68 Vienna Programme of Action UN Doc. A/CONF 157/24 Part 1 ch. III. 
the African Children's Charter and the African Women's Protocol, all of which guarantee both civil and political rights and socio-economic rights.

Although there is no international human rights instrument that specifically provides for poverty as a human rights violation, there exist provisions under international agreements that can be indirectly invoked to support this assertion. For instance, the preamble to the Universal Declaration of Human Rights provides that that the ideal of free human beings enjoying freedom from fear and want can be achieved only if conditions are created whereby everyone may enjoy his or her economic, social and cultural rights, as well as his or her civil and political rights. ${ }^{69}$ In addition, article 25 of the UDHR guarantees the right of everyone to a standard of living adequate for the health and well-being of him- or herself and of his or her family, including food, clothing, housing and medical care and necessary social services, and the right to security in the event of unemployment. ${ }^{70} \mathrm{~A}$ similar provision exists in article 11 of the International Covenant on Economic, Social and Cultural Rights. The Committee on Economic, Social and Cultural Rights in one of its statements has emphasised the importance of integrating human rights into poverty eradication policies by outlining how human rights generally, and the Covenant in particular, can empower the poor and enhance anti-poverty strategies. $^{71}$

The GPs identify different rights which may be undermined by reason of extreme poverty to include right to life, liberty and security of persons, privacy, equality before the law, food, education, health, housing, adequate standard of living and sanitation. This approach coincides with the position of the United Nations during the Copenhagen Declaration on Social Development and the Programme of Action of the World Summit for Social Development where the international community affirms that poverty constitutes a violation of human rights. $^{72}$ The international community further committed to endeavouring to ensure that all men and women, especially those living in poverty, could exercise the rights, utilise the resources and share the responsibilities that would enable them to lead satisfying lives and to contribute to the well-being of their families, their communities and humankind. This position was reinstated at the World Conference against Racism, Racial Discrimination, Xenophobia and Related Intolerance where the international community deliberated on the impact of all forms of discrimination on extreme poverty. ${ }^{73}$ Since then there have been other resolutions by UN bodies calling for the adoption of a rights-based approach to poverty eradication. For instance, the Commission for Human Rights in one of its resolutions declared that 'Extreme poverty and exclusion from society constitute a violation of human dignity and that urgent national and international

69 UDHR, supra note 44.

70 Ibid.

71 International Covenant on Economic, Social and Cultural Rights, adopted 16 December 1966, GA Res. 2200 (XXI), UN Doc. A/6316 (1966) 993 UNTS 3 (entered into force 3 January 1976).

72 Copenhagen Declaration, supra note 8.

73 World Summit on Social Development in South Africa 2002. 
action is therefore required to eliminate them. ${ }^{74}$ In the same vein, the Human Rights Council has affirmed that the eradication of poverty warrants a rights-based approach. ${ }^{75}$ Also, the UN General Assembly in some of its resolutions has lent its voice to a rights-based approach to poverty calling on member states to give men and women living in extreme poverty the wherewithal to organise and participate in all aspects of political, economic and social life. ${ }^{76}$

At the African regional level, African governments through different initiatives have attempted to address the challenge of poverty in the region. The establishment of the New Partnership for Africa's Development (NEPAD) and the adoption of the Charter on participation and development are aimed at improving the overall economic situation in the region and consequently reducing the incidence of poverty. ${ }^{77}$ NEPAD was establish to address the challenges facing the African continent, particularly issues such as the escalating poverty levels, underdevelopment and the marginalisation of Africa, which require a new radical intervention, spearheaded by African leaders. Some of its underlying principles include good governance as a basis for realising political and economic development, anchoring the development of Africa on its resources and the resourcefulness of its people; acceleration of regional and continental integration; and ensuring that all Partnerships with NEPAD are linked to the Millennium Development Goals and other agreed development goals and targets.

Furthermore, the African Commission has developed some jurisprudence over the years that is useful in addressing the poverty situation in the region. For instance, in the SERAC case the Commission has been able to read the right to food into other rights of the Charter in the absence of an explicit provision on the right to food. ${ }^{78}$ In other cases, the Commission has found that a denial of access to housing, water, health and electricity constitutes a violation of various articles of the African Charter. ${ }^{79}$ This bold and progressive approach by the Commission suggests that it might be willing in future to hold that poverty constitutes a violation of human rights.

Some commentators have echoed the fact that poverty is a violation of individual rights. For instance, Pogge has argued that the existing institutional structure at international and national levels perpetuates inequality and poverty thus amounting to a gross violation of human rights. ${ }^{80}$ He further argues in favour of a moral human right that everyone has to a standard of living adequate for health and well-being. ${ }^{81}$ Also, Osmani has noted that poverty and human rights

\footnotetext{
74 See Commission on Human Rights, 'Human Rights and Extreme Poverty', Resolution 2004/23. 75 See for example Resolution 8/11 of 18 June 2008 on 'Human Rights and Extreme Poverty'. 76 Resolution 59/186 of 20 December 2004.

77 The NEPAD strategic framework document arises from a mandate given to the five initiating heads of state (Algeria, Egypt, Nigeria, Senegal and South Africa) by the Organization of African Unity (OAU) to develop an integrated socio-economic development framework for Africa. The 37th Summit of the OAU in July 2001 formally adopted the strategic framework document

78 SERAC case, supra note 51.

79 Ibid.

80 Pogge, supra note 56.

$81 \mathrm{lbid}$.
} 
are interrelated in two ways. First, poverty is a state of deprivations of all kinds and these deprivations constitute a denial of a range of human rights. ${ }^{82}$ Second, a denial of a range of human rights can lead to poverty. Building on Sen's capability approach, Osmani explains that poverty will amount to a denial of human rights because it fails to realise basic human capabilities. According to him, poverty can be described as a lack of capabilities to be free from hunger, to be able to lead a life free from avoidable mortality and morbidity, and to be able to appear in public with dignity.

Sen has similarly argued that since the capability approach strives at addressing deprivations that lead to poverty, it is in a way consistent with a rights-based approach to combating poverty. ${ }^{83}$ In Robinson's view, 'Extreme poverty is the greatest denial of the exercise of human rights... . It's a denial of the dignity and worth of each individual which is what the universal declaration proclaims. ${ }^{84}$ Examining poverty from a rights-based perspective emphasises the fact that persons living in extreme poverty are not the objects of sympathy or pity but rather the subjects of social injustice that deserve respect and protection. In essence, poverty often arises as a result of failure on the part of a state to create an enabling environment that will make vulnerable groups avoid poverty.

The notion that extreme poverty constitutes human rights violations is not without its critics. Some commentators have noted that it is misleading to argue that poverty constitutes human rights violations. Doz Costa has expressed scepticism for the application of human rights to the issue of poverty. ${ }^{85} \mathrm{He}$ notes that human rights activists are often unclear when they argue that poverty constitutes a human rights violation since there is no specific right directly dealing with this issue. ${ }^{86} \mathrm{He}$ argues further that it is often unclear who the duty-bearers are when it is asserted that poverty amounts to a human rights violation. Moreover, proponents of poverty as a human rights violation often rely on non-binding declarations rather than specific treaty obligations in this regard. ${ }^{87}$

Notwithstanding these criticisms of a rights-based approach to poverty, there seems to be a growing consensus under international law that extreme poverty does raise some human rights concerns. This is the approach the GPs have taken. The GPs highlight some of the important human rights that may be implicated as a result of experiencing extreme poverty. While it is admitted that extreme poverty may implicate both civil and political rights and socio-economic rights, there is no doubt that the latter forms of rights are more affected than the former. Given that extreme poverty is often a result of some form of deprivation, the GPs place the emphasis on socio-economic rights that may be implicated. In this regard, the GPs

82 S. R. Osmani, 'Poverty and Human Rights: Building on Capability Approach', 6 Journal of Human Development (2005): 205, 207.

83 A. Sen, 'Human Rights and Capabilities', 6 Journal of Human Development (2005): 153.

84 M. Robinson, Poverty and Human Rights: Sen's Capability Perspective Explored, Oxford University Press (2006), p. vi.

85 F. Doz Costa, 'Poverty and Human Rights: From Rhetoric to Legal Obligations: A Critical Account of Conceptual Frameworks', 9 SUR Internal Journal on Human Rights (2010): 80.

86 Ibid., at 81 .

87 Ibid. 
make reference to the rights to housing, work, health, social security, education and to take part in cultural life and benefit from scientific progress. ${ }^{88}$ It is a known fact that lack of access to healthcare services can compromise individuals' wellbeing and lead to poverty, and on the other hand poverty can aggravate ill health. In the same vein, a denial of the right of access to adequate housing, particularly for vulnerable and marginalised groups, often leads to poverty. Moreover, people who lack access to potable water and basic sanitation may suffer from health consequences which may compromise their well-being and living conditions.

In some of its jurisprudence, the African Commission has tended to make the link between violations of socio-economic rights and poverty. For instance, in the case involving Sudan, the Commission has found that the atrocities perpetrated by the Sudanese government against the people of Darfur violated some of the socioeconomic rights guaranteed in the African Charter, including rights to property, health and development. ${ }^{89}$ In another case involving mass eviction of some people from their homes, the Commission has found a violation of the rights to property and housing as guaranteed in the Charter.$^{90}$ Given the importance of land to wealth and as a form of escape from poverty in Africa, this decision is significant and coincides with applying a rights-based approach to poverty reduction in Africa.

The broad inclusion of various socio-economic rights in the GPs reinforces the importance of these sets of rights to improving the living conditions of people across the world. As noted earlier, some of the indicators adopted by the UNDP to measure development and standard of living among states are related to health, education and other social amenities. This would seem to buttress the point that poverty is more than mere lack but should be seen as a denial of access to basic necessities that make life worthy of living. Moreover, this would also imply that states should adopt policies and programmes that prioritise the interests of vulnerable and marginalised groups. This is very important, particularly in developing regions such as Africa, where sometimes crass mismanagement, misplaced priorities and kleptomania aggravate poverty situations among the people. It is, however, uncertain how states will respond to this bearing in mind that most countries do not explicitly recognise socio-economic rights as enforceable rights within their laws.

Interestingly, the GPs omit to make a direct link between extreme poverty and the right to development. To many developing countries this is a serious oversight, and it really became an issue during the process preceding the adoption of the GPs. It was contended that the right to development is fundamental to addressing extreme poverty in many parts of developing countries. ${ }^{91}$ While it is true that the GPs do not specifically mention the right to development, they nonetheless make

88 See paras $73-90$.

89 Sudan Human Rights Organisation \& Another v Sudan (2009) AHRLR 153 (ACHPR2009) (Darfur case).

90 See Centre for Minority Rights Development \& Others v Kenya (2009) AHRLR 75 (ACHPR 2009) (Endorois case).

91 The author participated in the 21st Session of the Human Rights Council in Geneva and witnessed the discussions preceding the adoption of the Guiding Principles. 
allusion to some rights such as water and sanitation that may have implications for the right to development. In response to this omission, the Special Rapporteur on extreme poverty and human rights Ms Carmona observes that while the GPs may not be a perfect document, it no doubt remains a useful tool to assess a state's commitment to addressing poverty as a human rights obligation. ${ }^{92}$

\section{Non-state actors and extraterritoriality obligation to combat poverty}

The GPs contain an interesting provision on the extraterritoriality of obligations to combat poverty. Given that the activities of rich countries or multinational corporations, in one way or another, may impact on extreme poverty in poor regions, the provision on extraterritoriality of obligation is a welcome development. The GPs declare thus:

States have a duty, in accordance with their international obligations, to prevent and protect against human rights abuse committed by non-State actors, including business enterprises, which they are in a position to regulate. Where transnational corporations are involved, all relevant States should cooperate to ensure that businesses respect human rights abroad, including the human rights of persons and communities living in poverty. States should take additional steps to protect against abuses of human rights by business enterprises that are owned or controlled by the State, or that receive substantial support and service from State agencies. ${ }^{93}$

This seems to coincide with the growing consensus under international law that home states of multinational corporations should be legally responsible for human rights violations occasioned by the activities of such corporations conducted outside of their jurisdictions. This assertion has recently been bolstered by the adoption of the Maastricht Principles on extraterritorial obligations of states in relation to socio-economic rights, where it is provided that 'All States have obligations to respect, protect and fulfil human rights, including civil, cultural, economic, political and social rights, both within their territories and extraterritorially. ${ }^{94}$ It should also be noted that under article 56 of the UN Charter member states commit themselves to taking joint and separate actions in cooperation with the UN to achieve the purposes set out in the Charter. Such purposes include: 'universal respect for, and observance of, human rights and fundamental freedoms for all without distinction as to race, sex, language, or

92 See Statement by Ms Magdalena Sepúlveda Carmona, Special Rapporteur on Extreme Poverty and Human Rights at the 21st Session of the Human Rights Council, available at http://www.ohchr.org/en/NewsEvents/Pages/DisplayNews.aspx?NewsID=12503\&LangID=E (accessed 28 February 2014).

93 See Draft Guiding Principles, supra note 37, para. 99.

94 Maastricht Principles on Extraterritorial Obligations of States in the area of Economic, Social and Cultural Rights, adopted in September 2011. 
religion'. ${ }^{95}$ What seems unclear about this, however, is whether a state that has not ratified the ICESCR will still be bound by the principle of extraterritoriality. It can be argued that the need to prevent extreme poverty cuts across civil and political rights and socio-economic rights. Therefore, the question should not be whether a state has ratified the ICESCR but whether a state is a member of the UN or has ratified any other human rights instrument. ${ }^{96}$

The Maastricht Principles will no doubt serve as a useful interpretative guide for the African Commission in interpreting the provisions of the African Charter. In line with articles 60 and 61 of the African Charter, the Commission can take into consideration the provisions of the Maastricht Principles in addressing human rights violations perpetrated by multinational corporations registered outside of the region. This is all the more important if such activities may have serious implications for poverty in the region. In this regard, the decision of the African Commission in the famous SERAC case provides a glimmer of hope that the Commission may likely apply the extraterritoriality of obligations in relation to socio-economic rights in future.

\section{E. Implementation}

To ensure the important provisions of the GPs are properly carried out so that they do not become mere aspirations, the drafters have included necessary and practical steps that states should adopt. Some of the important implementation requirements in the GPs include the fact that states must strive towards the immediate execution of the GPs and must refrain from taking retrogressive steps in this regard. More importantly, states are required to adopt a national strategy grounded in human rights principles and standards to combat extreme poverty. Such a strategy must be time bound with indicators and benchmarks and must clearly designate the authorities responsible for implementation of its various parts. In addition, states must allocate adequate resources to implement such a strategy. The main reason for the inclusion of these important provisions on implementation is to avoid a situation where the GPs will become a mere 'paper tiger'. It is a known fact that states are always looking for the slightest opportunity to avoid fulfilling their international obligations, particularly with regard to socio-economic rights. Measures to be taken by states may include adopting appropriate policies or enacting laws specifically to encapsulate the content of the GPs.

The GPs propose that in all actions taken towards implementing any strategy to address poverty, the interest and human rights of those living in extreme poverty must be prioritised. In essence, persons living in extreme poverty must be at the centre of any decision that may have serious implications for their socio-economic lives. In line with the reasoning of the Committee on ESCR, the GPs propose that

95 UN Charter, article 56-55, signed 26 June 1945, 59 Stat. 1031, TS No. 993, 3 Bevans 1153 (entered into force 24 October 1945).

96 For more on this issue see, O. De Schutter, A. Eide, A. Khalfan, M. Orellana, M. Salomon and I. Seiderman, 'Commentary to the Maastricht Principles on Extraterritorial Obligations of States in the Area of Economic, Social and Cultural Rights', 34 Human Rights Quarterly (2012): 1084-169. 
states should ensure that facilities, goods and services are accessible, available, acceptable and of good quality to persons living in extreme poverty. ${ }^{97}$ This is a crucial point given that extreme poverty often occurs due to various forms of deprivations.

In addressing the challenges posed by poverty across the world, there is a need for coherence in policy formulation at the international and national levels. This is an important point which has often been overlooked. Thus, policies are sometimes formulated at the international level to address poverty without proper consultation or harmonisation with national strategies or policies on poverty. The result is often duplication of effort or at worst confusion and incoherence in policy formulation to address poverty. Oftentimes, targets or benchmarks to address poverty are set at international or regional levels without assessing the capabilities of a state to attain them. The GPs aim at correcting this by advocating for cooperation between policy makers at the international and national levels. The African Commission has similarly echoed this position in its Guidelines for the implementation of socio-economic rights in Africa. The Commission has suggested cooperation among the different tiers of government within a country in order to jointly address the challenge posed by poverty. ${ }^{98}$

A point to make here is that the roles of civil society groups in implementing the GPs are not clearly articulated. Although the GPs do enjoin states to work with development agencies and national institutions to ensure the effective implementation of the provisions therein, no specific reference was made to civil society groups. It is a known fact that civil society organisations possess experience and knowledge about the poverty situation in many countries because they work directly with vulnerable and marginalised groups, including persons living in extreme poverty. They have the necessary facts and are able to ascertain the needs of persons living in extreme poverty. Moreover, they can assist states in developing indicators and benchmarks to monitor progress with regard to addressing extreme poverty. While it is agreed that states are the primary dutybearers of human rights instruments, civil society groups play a crucial role in assisting states to fulfil their obligations in this regard. It may be argued though that the non-reference to civil society organisations in GPs will not in any way diminish their importance in ensuring the proper implementation of the GPs.

\section{CONCLUSION}

By the adoption of the GPs the Human Rights Council has reinforced the importance of a rights-based approach to addressing poverty. Though not a binding document by any standard, the GPs contain provisions that will guide

97 See for instance, UN Committee on Economic, Social and Cultural Rights, General Comment 14, The Right to the Highest Attainable Standard of Health, UN Doc. E/C. 12/2000/4; see also the UN Committee on Economic, Social and Cultural Rights, General Comment 12, The Right to Adequate Food (Art. 11), UN Doc. E/C.12/1999/5.

98 See for instance, Principles and Guidelines on the Implementation of Economic, Social and Cultural Rights, supra note 59, para. 92(h). 
states and non-state actors in fulfilling their obligations to respect, protect and fulfil the rights of persons living in extreme poverty. The GPs, together with the Optional Protocol on Economic, Social and Cultural Rights, provide an additional tool for the Committee on Economic, Social and Cultural Rights to develop jurisprudence on poverty and other related rights at the international level. In the same vein, the GPs, together with the Principles and Guidelines on the Implementation of Economic, Social and Cultural Rights under the African Charter, presents a golden opportunity for the African Commission to further strengthen its jurisprudence on socio-economic rights, including issues relating to poverty reduction in the region.

It has further been argued that the GPs can potentially become strong tools for governments to design and implement poverty reduction strategies or policies targeted at persons living in extreme poverty. ${ }^{99}$ They can also become important advocacy tools for civil society organisations to hold governments accountable to their obligations in meeting the rights of persons living in extreme poverty. ${ }^{100}$ While the GPs focus on the rights of those vulnerable to poverty, such as, women, indigenous peoples, minorities, migrants, the internally displaced, children and orphans, they also serve the interest of the society at large. Ultimately, the GPs can serve as a catalyst for states to realise their commitment under the MDGs, particularly goal 1 . 